Images in...

\title{
Syringocystadenocarcinoma papilliferum at unusual site: inherent lesional histologic polymorphism is the pathognomon
}

\author{
Andleeb Abrari, Urmi Mukherjee \\ Histopathology Department, Max Super Specialty Hospital, New Delhi, India
}

Correspondence toDr Andleeb Abrari, abrariand@gmail.com

\section{DESCRIPTION}

Syringocystadenocarcinoma papilliferum is an extremely rare cutaneous adnexal carcinoma, considered by the $\mathrm{WHO}$ as the malignant form of syringocystadenoma papilliferum (SCAP). ${ }^{1}$

The rarity of this tumour has been referred to, in a recent paper $^{2}$ which reviews the entity and lists a total of 12 reported cases till 2010, since it was first described in $1980 .^{3}$ Eight of these 12 cases were reported to have occurred in the head and neck region (six on the scalp, one in the neck, one on the auricle), sites other than head and neck were distinctly uncommon. ${ }^{2}$

This malignant tumour having a predilection for the scalp, in older people, is a composite of a SCAP-like lesion superficially and an infiltrative adenocarcinoma in the deeper component. ${ }^{4}$

The benign precursor usually antedates the malignancy by many years, as a non-progressive verrucous lesion; and when congenital, there is a frequent association with naevus sebaceous.

In older people, the presence of solitary cutaneous adenocarcinoma leads to clinical consideration of a metastatic versus primary cancer; systematic morphologic analysis, will usually resolve the issue, as illustrated in the present tumour, which occurred in a 62-year-old male, in the axilla, where syringocystadenocarcinoma papilliferum is practically unknown. As described by the patient, a bead like, $1.0 \mathrm{~cm}$ axillary swelling, had been self-discovered and this lesion had excoriated and attained a size of $3.5 \mathrm{~cm}$ in 6 months. The clinical differentials included malignant change in a pre-existing adnexal neoplasm and metastatic malignancy in a superficially located axillary lymph node.

The histology showed a villiform superficial portion, in continuity with 'ducts' bearing the 'in situ' component of the tumour and the deep, infiltrating adenocarcinoma -

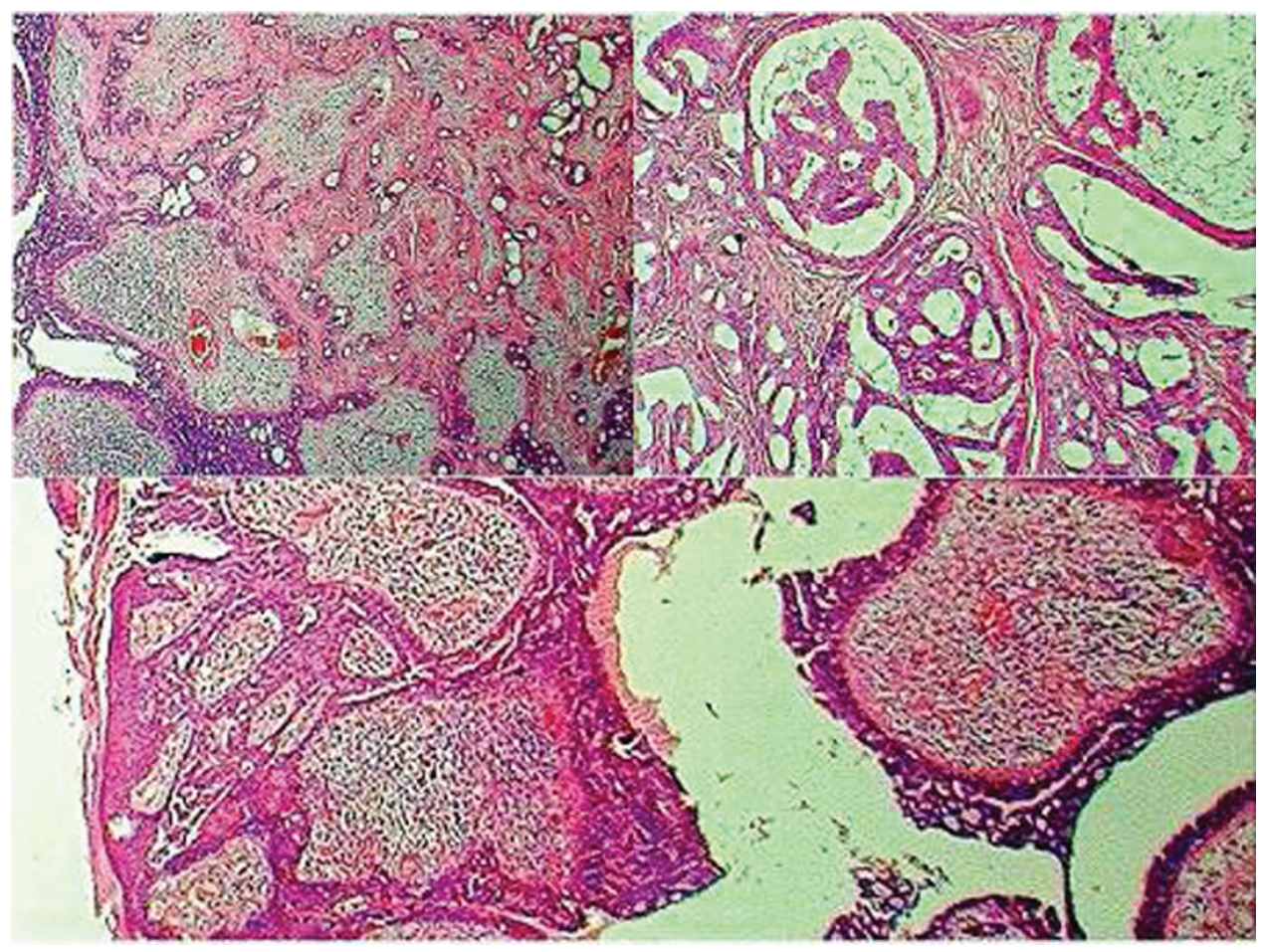

Figure 1 Composite micrograph showing the papillarysuperficial portion of the tumour $(1,2,4)$, the 'in situ ' component $(1,4)$; and deeper located infiltrating adenocarcinoma $(1,2,3)$. 


\section{BMJ Case Reports}

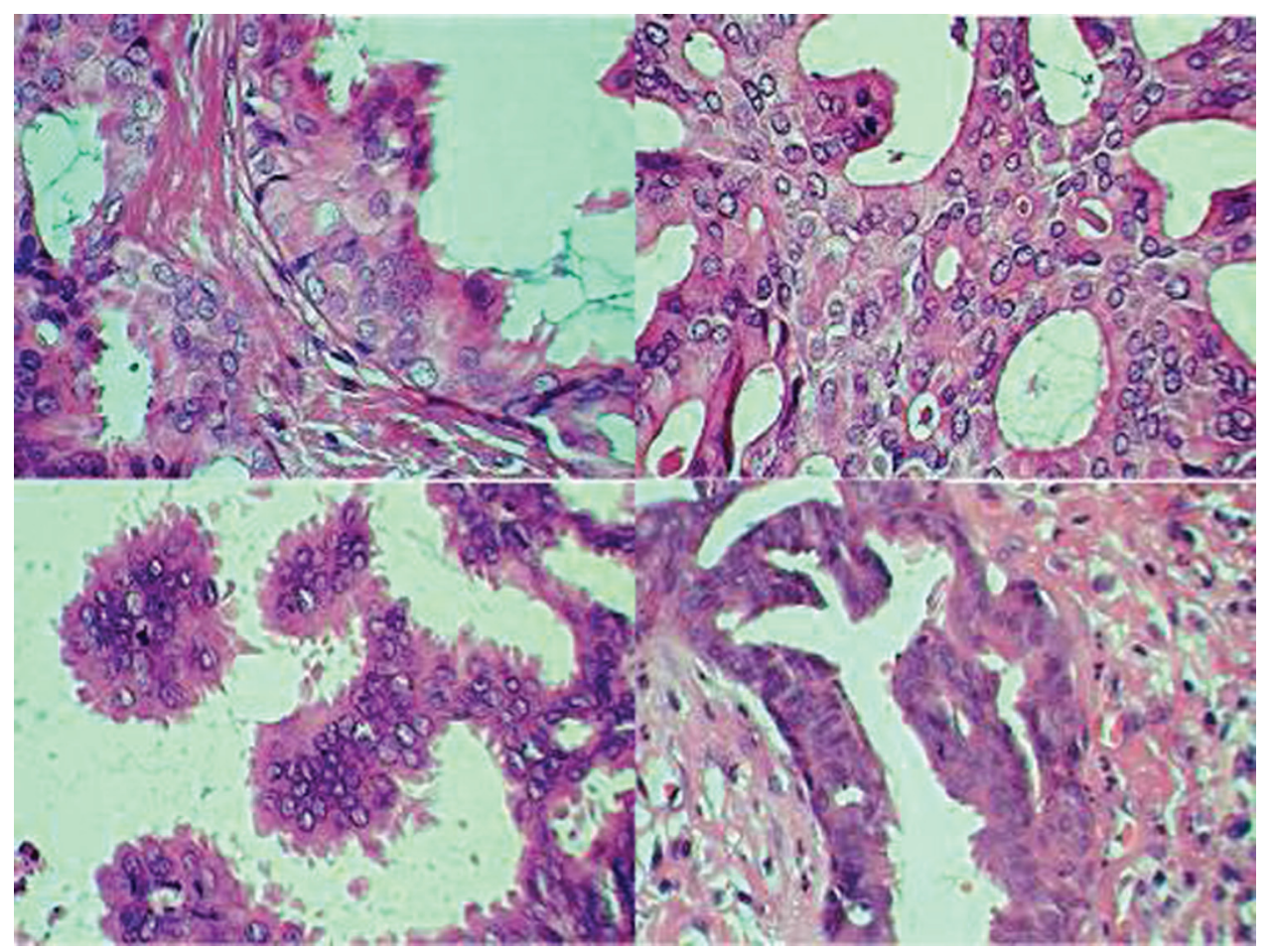

Figure 2 Composite micrograph depicting the morphologic heterogeneity - papillary intraductal pattern with decapitation secretions(3), clinging (1), cribriform (2) and columnar cell (4), patterns.

distinguished by acini, tubules and ducts, with polymorphous architecture (figure 1). ${ }^{1}$

Cribriform, papillary intraductal, clinging and columnar cell patterns with focal apocrine like decapitation secretions observed, closely resembled the similarly named mammary counterparts figure 2.45

The educational message highlighted is that syringocystadenocarcinoma papilliferum, will very rarely occur at atypical locations and the distinctive histology should afford ineffable means of an accurate diagnosis.

Competing interests None.

Patient consent Obtained.

\section{REFERENCES}

1. Woestenborghs H, Van Eyken P, Dans A. Syringocystadenocarcinoma papilliferum in situ with pagetoid spread: a case report. Histopathology 2006; 48:869-70.

2. Leeborg $\mathbf{N}$, Thompson M, Rossmiller $\mathrm{S}$, et al. Diagnostic pitfalls in syringocystadenocarcinoma papilliferum: case report and review of the literature. Arch Pathol Lab Med 2010;134:1205-9.

3. Dissanayake RV, Salm R. Sweat-gland carcinomas: prognosis related to histological type. Histopathology 1980;4:445-66.

4. Park SH, Shin TM, Shin DH, et al. Syringocystadenocarcinoma papilliferum: a case report. J Korean Med Sci 2007;22:762-5.

5. Kazakov DV, Requena L, Kutzner H, et al. Morphologic diversity of syringocystadenocarcinoma papilliferum based on a clinicopathologic study of 6 cases and review of the literature. Am J Dermatopathol 2010;32:340-7.

This pdf has been created automatically from the final edited text and images.

Copyright 2011 BMJ Publishing Group. All rights reserved. For permission to reuse any of this content visit http://group.bmj.com/group/rights-licensing/permissions.

BMJ Case Report Fellows may re-use this article for personal use and teaching without any further permission.

Please cite this article as follows (you will need to access the article online to obtain the date of publication).

Abrari A, Mukherjee U. Syringocystadenocarcinoma papilliferum at unusual site: inherent lesional histologic polymorphism is the pathognomon. BMJ Case Reports 2011;10.1136/bcr.05.2011.4254, date of publication

Become a Fellow of BMJ Case Reports today and you can:

- Submit as many cases as you like

- Enjoy fast sympathetic peer review and rapid publication of accepted articles

- Access all the published articles

- Re-use any of the published material for personal use and teaching without further permission

For information on Institutional Fellowships contact consortiasales@bmjgroup.com

Visit casereports.bmj.com for more articles like this and to become a Fellow 